\title{
VORCARO, A \\ Crianças na Psicanálise Clínica, Instituição, Laço Social
}

Rio de Janeiro, Cia. de Freud, 1999

\section{Renata De Luca}

Nesse seu livro, Angela Vorcaro demonstra uma destreza ao articular conceitos psicanalíticos que dizem respeito ao trabalho com crianças que apenas a maturidade pode oferecer. E um livro maduro, de quem conhece a clínica - exerce suas atividades na Clínica de Distúrbios da Comunicação (Derdic) -, a transmissão - com trabalhos didáticos na PUC-SP e Unicamp - e, sobretudo, a teoria psicanalítica.

Valendo-se disso, a autora maneja conceitos e oferece luz a questões que permeiam o trabalho de quem se ocupa com crianças. Mas, leitor, prepare-se: a trilha é árdua! Para acompanharmos as articulações propostas, é necessário dispor de conceitos da psicanálise lacaniana, pois algumas partes do texto são bastante laboriosas.

$\mathrm{O}$ resultado final é engrandecedor. Fica-se com a impressão de ter desfrutado de uma importante contribuição ao trabalho com crianças, ou, como ela mesma diz, de um testemunho.

Já de entrada, na apresentação, é lançada uma questão sem meias palavras: uma psicanálise de/com crianças estaria à altura do discurso

Psicanalista, mestranda da Faculdade de Educação da Universidade de São Paulo. 
analítico? Ela seria uma "subpsicanálise", com seus cursos de formação à parte da formação de analistas e uma teorização que, nas palavras de Marie-Jean Sauret, cai facilmente na profilaxia ou na ortopedia psicanalítica: perspectiva analítica sob o signo da evolução?

Vorcaro, ousadamente, propõe uma inversão da questão: será que o discurso psicanalítico alcança a clínica com crianças?

Os profissionais que se ocupam desse campo sabem das dificuldades e dos vieses sedutores e comuns por onde podemos nos enveredar. $\mathrm{O}$ mais comum é o viés do apagamento da singularidade, em que se recorre à observação, classificações e métodos que dêem um lugar teórico para o que está fora na criança. Lançando mão de outros campos discursivos, a psicanálise abandona a singularidade em busca do conforto de uma resposta própria de um saber preestabelecido.

Um outro viés seria o engodo multidisciplinar: associando-se a teorias desenvolvimentistas de outras disciplinas, com base em uma dimensão imaginária, busca-se uma compreensão pela lógica da somatória das partes.

Tanto um viés, a teorização, quanto o outro, a imaginarização multidisciplinar do que vai mal com a criança, são formas comuns de abandono da "interrogação sobre a singularidade das manifestações da criança e [em que] escapa-se à ética da psicanálise”, segundo a autora.

A constatação da existência desses vieses e das ressalvas que são feitas no próprio meio psicanalítico a quem atende crianças leva Vorcaro a formular a questão "o que há na criança (de) insuportável?"

Todo o restante da apresentação está às voltas com essa resposta. Retomando a dificuldade freudiana, que percebe a criança como um ideal narcísico dos pais, mas fica à margem das questões que ela provoca, a autora dirá que o que Freud bordeja é o estatuto de real da criança.

Ou seja, tratar a criança implica um encontro do analista com o real do seu próprio gozo, que é presentificado na relação com a criança. "A criança, portanto, captura imediatamente o que há de mais singular no analista, porque ela convoca o seu fantasma" (p.15). Não estaria aí a verdadeira dificuldade da psicanálise, desde Freud, em se ocupar com crianças? Nessa exposição que ela traz do analista ao indizível do real?

Um outro ponto a ser recortado dessa especificidade é o ético: considerando a estruturação subjetiva não resolvida na criança, a responsabilidade do analista é outra, pois existe aí a possibilidade de uma resolução. A autora dirá que o analista irá agir sobre um não, pois trata-se de uma estruturação incompleta, inacabada, 
ou na qual tenha havido um lapso. E que a análise de crianças incidirá sobre a forma que foi transmitida à estrutura.

Sob esse ponto de vista estrutural, Vorcaro faz uma afirmação fundamental para o analista que se ocupa de crianças com distúrbios globais do desenvolvimento, em que distúrbios ou ausência de fala/linguagem são bastante comuns: "Situar a criança na estruturação subjetiva exige a hipótese de que não há insuficiência de linguagem em nenhuma criança, a despeito dos modos como ela se apresenta. Há condições de circulação significante na trajetória lógica de sua estruturação e no aprisionamento a impasses que podem ser gerados nessa trajetória. Abordar a realidade psíquica da criança implicará o recolhimento do tecido significante articulado pelos sentidos, localizando neles marcas que balizam sua constituição para reconhecer as senhas que poderão operar sua leitura” (p.13).

Esses mesmos distúrbios de fala ou linguagem parecem ser o eixo de uma parte do livro que diz mais respeito à prática das disciplinas. Analisando a dinâmica da Derdic, a autora reflete sobre a aproximação das disciplinas, principalmente fonoaudiologia e psicologia, no tratamento de crianças com esses distúrbios. Ela falará de um traço comum às instituições: o pedido à psicologia feito por outras disciplinas de uma compreensão e orientação desses casos em que se percebe um para além do orgânico. Essa posição imaginária de um saber privilegiado da psicologia que poderia vir a obturar a falta de outras disciplinas.

Ao responder a esse lugar imaginário, com suas avaliações e diagnósticos, a psicologia contribui para a rolagem de uma dívida conceitual: "A de um diagnóstico que seja capaz de sustentar o laço que ata a patologia de linguagem ao falante que a veicula" (p.127).

Essa observação que a autora faz do que está implícito no pedido da fonoaudiologia à psicologia pode ser estendida a outras disciplinas que se ocupam de crianças em dificuldades. A ilusão somatória das equipes multidisciplinares e a tentativa de se encontrar o ideal técnico fundamentam o cotidiano institucional.

A autora lançará ainda um olhar sobre a psicopedagogia, seguindo esse mesmo eixo das práticas clínicas e escolares que envolvem o trabalho com crianças. Baseando-se em uma pesquisa realizada na Universidade Paulista que reflete acerca do crescente número de cursos de psicopedagogia no Brasil, ela dirá que esse aumento poderia ser uma forma de responder a um sintoma social: cria-se uma prática voltada à sintomatologia da aprendizagem e a lacuna das disciplinas que se ocupam dela para que ela dê conta de explicar o fracasso escolar. 
Como possibilidade, restaria a uma psicopedagogia a serviço do sujeito, e não apenas do sintoma, ofertar às outras disciplinas conhecimentos que digam respeito aos paradigmas que possibilitam ao sujeito aprender. Em vez de situar-se entre a psicologia e a pedagogia, ela poderia ocupar um lugar "para além" dessas disciplinas e seus campos teóricos.

Assim, tocando em dois "ícones" da clínica atual com crianças, os distúrbios de linguagem e o fracasso escolar, Vorcaro oferece reflexões acerca da interdisciplinaridade, do cotidiano institucional e de engates teóricos que fundamentam o trabalho analítico com crianças.

Ela perseguirá dois conceitos teóricos, aos quais somará muitos outros, para pensar as psicopatologias infantis e a especificidade do analista que busca intervir sobre elas.

Retomando o texto lacaniano sobre as operações de causação do sujeito, a alienação e a separação, ela desdobrará esses conceitos para situá-los nas estruturas clínicas, interrogando-se sobre o lugar de onde um sujeito comparece realizado em holófrase no autismo, na psicose, na debilidade e nos fenômenos psicossomáticos.

A partir daí, valendo-se de fragmentos clínicos que auxiliam a compreensão dessa parte densa de sua exposição, discute a intervenção do analista na constituição do sujeito e a direção do tratamento nessas patologias graves e precoces.

O segundo conceito teórico que a autora persegue, e que faz o enlace com a parte mais "prática" do livro, é o conceito de transferência. Para tanto, ela retrocede e trabalha duas questões: como ler as manifestações de uma criança e qual seria a direção do tratamento. Após essa retomada, discorrerá acerca da posição do analista nas distintas estruturas clínicas, presentificada no movimento transferencial.

Para concluir, retomamos a apresentação do livro, em que a autora diz que oferecerá um testemunho da clínica com crianças, expondo-o à refutação do leitor. Faz disso uma aposta. Nesse convite ao jogo, fica a sensação de que a autora, como todo grande jogador que conhece seu jogo, instiga-nos a pensar sobre ele, a arriscar, a saber mais. Sem, no entanto, contar-nos os segredos da sua aposta. Mesmo porque precisamos supor que eles estão bem guardados, em nossa busca de alcançá-los. Suposto saber que nos permite continuar avançando.

\section{REFERÊNCIA BIBLIOGRÁFICA}

Lacan, J. (1964). O seminário, Livro XI, Os quatro conceitos fundamentais da psicanálise (M. D. Magno, trad.). Rio de Janeiro, RJ: Jorge Zahar, 1985. 